DEPARTAMENTO DE DOENÇAS INFEC'IUOSAS F PARASITARIAS

Diretor: Prof. Dr. Laerte Machado Guimarāes

DEI'AKTAMNTO DE HIGIRNF, E POI.FCIA SANITARIA ANIMAL

Diretur: Prof. Dr. Theodoro Iion de Araujo

\title{
NUTALIOSE CONGENITA EM EQUINOS PURO-SANGUE DE CORRIDAS NO ESTADO DE SÃO PAULO (*)
}

$$
\text { (PRIMEIRAS OBSERVAÇסES) }
$$

I. M. Guimarāes

T. L. Araujo

\author{
C. E. SAlles ComkS
Assistente \\ 1 estampa (1 gravura)
}

Em trabalho publicado em 1950 relatamos nossas obserrações sôbre a ocorrência da nutaliose em equinos puro-sangue de corrida em São Paulo. Até aquela oportunidade tínhamos assinalado a doença em 11 animais que estavam alojados há tempos na Vila Hípica do Jockey Club de São Paulo.

Devido ao modo pelo qual são mantidos, êsses animais seguramente se infestaram depois de terem dado entrada naquela dependência do Jockey Club. Posteriormente livemos ocasião de diagnosticar clínica e microscòpicamente nu. merosos casos de nutaliose equina na mesma Vila Hípica, mas sempre em ca. valos de 2 a 8 anos hípicos. Conheciamos da literaluri a existência de observaçōes de casos de "piroplasmose" congênita. Assim, em 1924, Donatien e col. assinalaram a presença de piroplasma em burro jovem no Poitou. Anteriormen. 1e, Carpano, em 1922, já havia tratado da transmissão placentária da piroplas. mose e sôbre o mesmo assunto escreveram, entre outros. Donatien e col. em 1934 no caso particular da passagem através da placenta de Babesiella otis e A. ovis, Konstantinof em 1936.

Por outro lado, há tempos vinha nos preocupando uma série de casos de doença de potros recém-nascidos, muitos com fim letal, e na maioria caracterizados por intensa icterícia. A crença mais geral nos meios técnicos era de que tais casos eram de eritoblastose ou icterícia dos recém-nascidos.

Kim agôsto de 1953, num Haras localizado no Município de Cotia, encontramos numa lâmina de sangue de potro de 10 dias de idade, que se apresen-

(") Comunicuğ̈n feita no IV Congressn Pan-.Mmericano de Medicina Veterinárin - 
tava com pronunciada icterícia, dois erifrócilos parasitados por formas lápicas de N. equat. Tratado com tripallasina, recuperoulse em 48 horas. l'ina scmana após rssa obsersaçāo, no mesmo Haras, encontrámos numa lami:ıa de sangue de outro potro de 1.2 semanas de idade as mesmas formas cararterjalicas do parasita. Submetido ao mesmo tratamento que o do caso anterior, o animal se res. tabeleceu. Em outro Haras do mesmo Municipio um potro imedialamente or. pois do nascimento apresentou-se com grande prostraçâo e icterícia. Com 48 horas de vida sua temperatura clevou-se a $410.3^{\circ} \mathrm{C}$ e a ictericia acentuou-se. Nise momento o exame de sangue denimustrou a presença das várias formas de $N$. equi, inclusive as em "Crue de Malta" (fig. 1). Fsse potrinho embora tratado não sobreviveu. $O$ sangue da igua. quir também estava febril e ictérica, se apresentava igualmente parasitado. Considerando a idade dêsses animais, particularmente a do íltimo, parece não caber dúvida de que estávamos frente a casos de nutaliose congentita, pois não seria admissivel que no espaço de poucas horas, como no últimn caro, ou de poucos dias como nos dois primeiros, pudessem os potrinhos se infrstar, decorrer o periodo de incubação e aparecerem os sintomas da doença. Vale notar que em outros Haras do Estado de São Paulo já havíamos encontrado, como dissemos anteriormente, vários casos de icterícia em potros recém-nascidos, sem que tivéssemos tido oportunidade de realizar exames de sangue, meio seguro de despistar a presença de Nultallia equi e portanto de confirmar o diagnóstico de nutaliose.

CONGF:NITAI, NUTTALIASIS OF THOROUGHBREI) RACE HORSES IN THE, STATK OF SAO PALLO

\section{(First observations)}

I:1 a previous paper (1950) our observations on the occurrence of Nutlalliasis of thuroughbred race horses in São Paulo were recorded. To that date 11 sick animals lodged at the Vila Hipica of the Jockey Club of São Paulo were oliserved.

The horses were assuredly infected after having been placed in that section of the lockey Club. We had subsequently the opportunity of making a clinical and microsiopical diagnosis of several cases of nuttalliasis occurring at the same place but only in $\mathbf{1 . 8}$ years old horses. We were aware of the literature on rongenital piroplasmosis, among others we may mention the following: Doxaritis and assuciates (1924) recorded the presence of Piroplasma in a young mule at Puitou. Carpano (1922) had written on the placental transmission of piroplasmosis. Konstantinof (1936). Dovatiex and associates (19:35). Donat and 
a:sociates (1934), on the case of transmission of Babesiclla ovis and A. ovis ihrough the placenta.

On the other hand we had heen worrying aboul a series of cases of disease of new born colts, many of them ending with death, and on the majority character. ized by an intense juundice. The general belief among experts was that such cases were erythroblastosis or jaundice of the new born.

In August 1953, in a haras of the Cotia country, we found in the blood of a 10 days old colt suffering from a seriour jaundice, two erythrocytes parasitized by typical forms of $N$. equi. Upon the administration of tripaflavine the foal recovered within 48 hours. One week later, at the same place, we found the same forms of the prarasite in another, 1.2 weeks old, colt. Same treatment a the previous one recovered the animal. In another stud farm, at the same locality, a cold showed great prostration and jaundice soon after its hirth. Within is hours its temperature rose to $40.8^{\circ} \mathrm{C}$ and the jaundice deepened. At this time the blood tests revealed the presence of the several forms of $N$. equi, inclusive of the "Maltest. Cross". This baby colt did not survive in spite of the treat. ment. The blood of the mare, which was also feverish and showed jaundice, was equally parasitized.

If we consider the age of these animals, and especially of the latter one. there seems to be no doubt that we were in the cases recorded, that the colts could get infected, the incubation period complete and the symptoms become ap. parent within a few hours or a even a few days.

It is worthwhile recording that in other stud farms of this State we had already hat the opportunity of finding several cases of jaundice in new born colts. We could not however examine the blood, this being the proper way (") detect the presence of Nuttallin equi in order to confirm the diagnosis of nut. talliasis. 



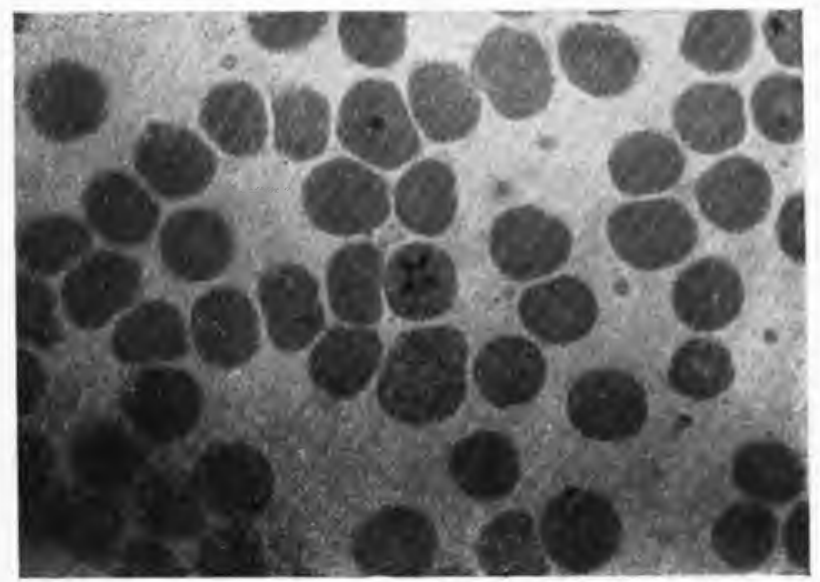

lig. 1 